ZOOLOGIA 30 (2): 221-226, April, 2013

http://dx.doi.org/10.1590/S1984-46702013000200013

\title{
New synonymies and a revalidation in the spider genera Eustala and Micrathena (Araneae: Araneidae)
}

\author{
Herbert W. Levi \& Adalberto J. Santos ${ }^{2,3}$
}

\author{
${ }^{1}$ Museum of Comparative Zoology, Harvard University. Cambridge, Massachusetts 02138, USA. E-mail: levi@fas.harvard.edu \\ 2 Departamento de Zoologia, Instituto de Ciências Biológicas, Universidade Federal de Minas Gerais. Avenida Antonio Carlos \\ 6627, 31270-901 Belo Horizonte, MG, Brazil.E-mail oxyopes@yahoo.com \\ ${ }^{3}$ Corresponding author. E-mail: oxyopes@yahoo.com
}

\begin{abstract}
In this study, 10 nominal species of Eustala Simon, 1895 are synonymized with other species of the genus, mostly based on matching males and females erroneously described as different species. Parawixia rimosa (Keyserling, 1892 ) is considered a senior synonym of Eustala decemtuberculata Caporiacco, 1955. Eustala isosceles Mello-Leitão, 1939 is transferred to Kapogea Levi, 1997 and considered a senior synonym of Kapogea alayoi (Archer, 1958) based on abdomen shape and coloration. Micrathena beta Caporiacco, 1947 is redescribed, illustrated and transferred from Linyphiidae back to Araneidae. This species can be easily distinguished from other members of the genus by the male palpus with an enlarged and modified paracymbium and a narrower hook as a conductor. Micrathena sanctispiritus Brignoli, 1983 is removed from the synonymy with M. lindenbergi Mello-Leitão, 1940 and considered a senior synonym of M. guanabara Levi, 1985.
\end{abstract}

KEY WORDS. Kapogea; Neotropical region; Parawixia; taxonomy.

Araneidae is among the most diverse spider families in the neotropics (Platnick 2013). Most of the Neotropical genera of the family have been revised between 1968 and 2007 (SANTOS et al. 2005, Levi 2004, 2007, see references in Levi 2002: table 1). However, several particular taxonomic problems remain, as well as undescribed species, even in revised genera. In this study, we correct some of these problems on two genera, Eustala Simon, 1895 and Micrathena Sundevall, 1833.

Eustala has not been revised recently, although illustrations of types of most species are available on-line (Levi 2008, Levi et al. 2010). During the process of preparing and uploading images on the internet, some synonyms have been found, which are mostly related to the fact that males and females are difficult to match. This problem lead CHICKering (1955) to describe males and females of this genus as separated species, even when specimens were collected in the same locality. However Willis J. Gertsch, who has also done field work in Panama, has matched males and females of several species (in letter to HWL, 30 September 1975), discovering the synonyms formalized in this paper.

Micrathena currently includes 115 species distributed from southern USA to northern Argentina (Levi 1978, 1985, MagalHÃES \& SANTOS 2011, 2012). In the most recent revision of the neotropical species of this genus (Levi 1985), Micrathena beta Caporiacco, 1947 was omitted and accidentally misplaced into Linyphiidae. Shortly after the publication of that revision, the holotype of another species, Micrathena sanctispiritus Brignoli, 1983, which was considered lost until then, was rediscovered. It soon became evident that this species was erro- neously considered a junior synonym of M. lindenbergi MelloLeitão, 1940 by Levi (1985). In this study, we propose modifications on the classification of both genera, in an attempt to fix the problems highlighted above.

\section{MATERIAL AND METHODS}

Specimens examined are deposited in the following institutions (curators in parentheses): AMNH, American Museum of Natural History, New York (N.I. Platnick); BMNH, The Natural History Museum, London (J. Beccaloni); MBUV, Museo de Biología, Universidad Central de Venezuela, Caracas (F. Rojas); MCZ, Museum of Comparative Zoology, Harvard University, Cambridge (G. Giribet); MNRJ, Museu Nacional, Universidade Federal do Rio de Janeiro, Rio de Janeiro (A.B. Kury), MZUF, Museo di Storia Naturale dell'Univerisità di Firenze. Sezione di Zoologia "La Specola", Firenze (S. Whitman); NHMB, Naturhistorisches Museum, Basel (E. Sutter, A. Hänggi); PAN, Polska Akademia Nauk, Warsaw (J. Proszynski). Description format follows Levi (1985), all measurements are in millimeters.

\section{TAXONOMY}

\section{Eustala Simon, 1895}

Remarks. Eustala is possibly closest to Metazygia F.O.P.Cambridge, 1904, as suggested by the anteriorly projecting scape of the epigynum (Levi 1977: figs 159; Levi, 1995: figs 253, 263, 270), the bubble-shaped terminal apophysis of the male palpus 
and the laterally placed, spineless median apophysis (Levi 1977: 232). Although these characters are not present in all species of Metazygia, neither of them is found in other araneids. This proposition is in conflict with results of SCHARFF \& CoDdington (1997), in which those genera are not sister groups, though they are relatively close. This disagreement might be resolved by repeating ScharfF \& Coddington (1997) analysis with improved sampling, both of species and characters. Those authors included only a single species of each genus in their analysis, despite variability in the scored characters within some genera. Additionally, genitalic organs, a source of many useful taxonomic characters over the decades, could supply many additional characters for a more complete quantitative analysis.

Another possible relative of Eustala is Acusilas lepidus (Thorell, 1898), from Burma, which shares with Eustala the presence of a similar cone-shaped median apophysis, which is placed laterally, and a long prong at the apex of terminal apophysis (Fig. 1). This proposition should be evaluated in the future, and can suggest that this species is misplaced in Acusilas Simon, 1895. It was originally described as Argiope lepida Thorell, 1898 and was transferred to Acusilas because of the narrow cephalic region of the carapace (Levi 1983). However, this species is remarkably different from other species of Acusilas, including its type species (Schmidt \& ScharfF 2008). Schmidt \& SCHARFF (2008) included Acusilas coccineus Simon, 1895 in SCHARFF \& Coddington's (1997) matrix and concluded the genus is close to Cyrtophora Simon, 1864 and Mecynogea Simon, 1903. We think the inclusion of $A$. lepida in an expanded araneid matrix would be important both to correctly test the monophyly of Acusilas and to determine the close relatives of Eustala.

\section{Eustala fuscovittata (Keyserling, 1864)}

Epeira fuscovittata Keyserling, 1864: 129, pl. 6, figs 7-8 (female holotype from Bogotá, Colombia, in BMNH, examined).

Eustala fuscovittata, F.O.P.-Cambridge, 1904: 505, pl. 48, figs 34; Alayón, 1995: 20; Levi, 2008; Platnick, 2013 (complete synonymic list).

Eustala anastera vermiformis Franganillo, 1931: 44 (type material from Cuba, not found, probably lost). Syn. nov.

Eustala procurva Franganillo, 1936: 80, fig. 37 (female holotype from Cuba, not found, probably lost). Syn. nov.

Eustala richardsi Mello-Leitão, 1939: 105, figs 1-4 (female holotype from Guyana, in BMNH, examined). Syn. nov.

Remarks. Although the type material of Franganillo's Cuban species has not been found in any Cuban collection, the original description and illustrations provided enough information for nomenclatorial decisions. Franganillo (1931) gave a vague, four-line description for E. anastera vermiformis, but this description suggests the epigynum is similar to that of the widespread $E$. fuscovittata, which has been previously recorded from Cuba (Alayón 1995). Franganillo's (1936) illustration of E. procurva epigynum matches that of E. fuscovittata, as well as the drawing of the lateral aspect of the abdomen.

\section{Eustala nasuta Mello-Leitão, 1939}

Eustala nasuta Mello-Leitão, 1939: 107, figs 5-6 (female holotype from Guyana, BMNH, examined); Levi, 2008, Poeta et al., 2010: 273, figs 32-33.

Eustala tumida Chickering, 1955: 508-511, figs 131-132 (female holotype from Summit, Canal Zone, Panama, VIII.1950, MCZ 23372, examined). Syn. nov.

\section{Eustala histrio Mello-Leitão, 1948}

Eustala histrio Mello-Leitão, 1948: 165, fig. 8 (female holotype from Guyana, BMNH, examined); Levi, 2008.

Eustala venusta Chickering, 1955: 515-517, figs 139-140 (female holotype from Barro Colorado Island, Canal Zone, Panama, VII.1950, MCZ 23465, examined. Paratypes from the same locality, examined: 2 females (MCZ 24454) VI-VII.1934; 3 females (MCZ 24450); 2 females (MCZ 24451); 1 female (MCZ 24452); 4 females (MCZ 24453); 11 females (MCZ 24455), all collected in VI-VII.1939. 1 female (MCZ 24457); 2 females (MCZ 24458); 1 female (MCZ 24459), all collected in 1950); Levi et al., 2010. Syn. nov.

\section{Eustala guianensis (Taczanowski, 1873)}

Singa guianensis Taczanowski, 1873: 124 (female holotype from Guyana, PAN, examined).

Aranea orina Chamberlin, 1916: 248-249, pl. 19, fig. 3 (male holotype from San Miguel, Cuzco, Peru, VII.1911, H.W. Foote coll., MCZ 227, examined). Syn. nov.

Eustala orina, Levi, 1991: 177; Levi, 2008.

Remarks. The type of E. guianensis is a female from Guyana but a male and a female collected together in Amable Maria, Junin, Peru, were found in the Taczanowski collection (PAN). The male of this sample is indistinguishable from the holotype of Eustala orina. Additionally, both Eustala guianensis and E. orina have similar black patches on the abdomen (see Levi 2008).

\section{Eustala bucolica Chickering}

Eustala bucolica Chickering, 1955: 425-428, figs 41-44 (male holotype from Boquete, Chiriqui, Panama, VIII.1939, MCZ 20620, examined. Paratypes from the same locality, examined: VIII.1950, 4 males (MCZ 24514); VIII.1939, 1 male (MCZ 24515)); Levi et al., 2010.

Eustala panama Chickering, 1955: 480-484, figs 103-105 (female holotype from Cerro Punta, Chririquí, Panama, III.1936, W.J. Gertsch leg., AMNH). Syn. nov.

\section{Eustala conformans Chamberlin, 1925}

Eustala conformans Chamberlin, 1925: 216 (female holotype from Barro Colorado Island, Canal Zone, Panama, W.C. Allee leg., MCZ 1273, examined); Chickering, 1955: 430, figs 49-50; Levi, 2008.

Eustala gertschi Chickering, 1955: 440-442, figs 59-62 (male 
holotype from Barro Colorado Island, Canal Zone, Panama, VI.1950, MCZ 21453, examined. Male paratype from the same locality, 11.VI.1948, MCZ 24520, examined). Syn. nov.

\section{Eustala ingenua Chickering, 1955}

Eustala ingenua Chickering, 1955: 449-452, fig. 73 (female holotype from Summit, Canal Zone, Panama, VII.1950, MCZ 21645 , examined. Female paratype from the same locality and date, MCZ 24521, examined); Levi et al., 2010.

Eustala longembola Chickering, 1955: 458-461, figs 81-85 (male holotype from Barro Colorado Island, Panama, VIII.1939, MCZ 21867, examined. Paratypes from Panama, examined: Canal Zone: Summit, VII-VIII.1950, 1 male (MCZ 24540); Madden Dam, VII.1950, 1 male (MCZ 24541); VIII.1939, 1 male (MCZ 24542); Forest Reserve, VII-VIII.1939, 3 males (MCZ 24543); VIII.1936, 1 male (MCZ 24544); Barro Colorado Island, VII-VIII.1936, 3 males (MCZ 24532); 1 male (MCZ 24533); VII-VIII.1950, 1 male (MCZ 24534); VI.1950, 2 males (MCZ 24535); VIII.1939, 1 male (MCZ 24536); VII.1937, 1 male (MCZ 24537); Fort Sherman, 1 male (MCZ 24539); Colón: Mount Hope, no date, 1 male (MCZ 24538); Coclé: El Valle de Antón, VII.1936, 3 males (MCZ 24547); Panamá: Arraijan, VII.1950, 2 males (MCZ 24545); VIII.1936, 1 male (MCZ 24546); Chilibre, VII.1950, 1 male (MCZ 24548); road to Chiva Chiva, VII.1950, 6 males (MCZ 24549)). Syn. nov.

\section{Eustala montivaga Chickering, 1955}

Eustala montivaga Chickering, 1955: 478-480, figs 101-102 (female holotype and female paratype from El Volcán, Chiriqui, Panama, VIII.1950, MCZ 22200 and 24531 respectively, examined).

Eustala montana Chickering, 1955: 474-478, figs 97-100 (male holotype and male paratype from El Volcán, Chiriqui, Panama, VIII.1950, MCZ 22161 and 24530 respectively, examined); Levi et al., 2010. Syn. nov.

\section{Eustala tantula Chickering, 1955}

Eustala tantula Chickering, 1955: 505-507, figs 128-130 (male holotype from Barro Colorado Island, Panama, VIII.1939, MCZ23230, examined. Paratypes from Panama, examined: Canal Zone: Barro Colorado Island, VII.1936, 1 male (MCZ 24488); Forest Reserve, VII-VIII.1939, 1 male (MCZ 24489); Fort Sherman, VIII.1939, 5 males (MCZ 24487); Madden Dam, VIII.1939, 1 male (MCZ 24486); Chiriqui: Boquete, VII.1939, 1 male (MCZ 24493); Coclé: El Valle de Antón, VII.1936, 1 male (MCZ 24490); Panamá: Chilibre, VII.1939, 1 male (MCZ 24492); road to Chiva Chiva, VIII.1950, 1 male (MCZ 24491)); Levi et al., 2010.

Eustala minima Chickering, 1955: 471-474, figs 94-96 (female holotype from Barro Colorado Island, Panama, VI.1950, MCZ 22081, examined. Paratypes from Panama, examined: Canal Zone: Barro Colorado Island, VI-VIII.1936, 1 female (MCZ
24460); VII-VIII.1939, 8 females (MCZ 24461); VII.1950, 4 females (MCZ 24462); VI-VII.1934, 3 females (MCZ 24463); VI.1950, 1 female (MCZ 24473); Forest Reserve, VII-VIII.1939, 1 female (MCZ 24467); Fort Randolph, VIII.1936, 1 female (MCZ 24465); Maddem Dam, VIII.1939, 4 females (MCZ 24464); Chiriqui: Boquete, VIII.1950, 2 females (MCZ 24470); VII.1939, 4 females (MCZ 24471); Coclé: El Valle de Antón, VII.1936, 3 females (MCZ 24469); Colón: Porto Bello, VIII.1936, 2 females (MCZ 24472); Panamá: Arraijan, VIII.1936, 1 female (MCZ 24468); Chilibre, VII.1939, 2 females (MCZ 24466)). First erroneously synonymized with Eustala devia (Gertsch \& Mulaik, 1936) by Levi, 1977: 101. Syn. nov.

Remarks. The synonymy of E. minima with E. devia was an error, since the females of both species differ in the posterior view of the epigynum, though they are similar in ventral view.

\section{Parawixia rimosa (Keyserling, 1892)}

Epeira rimosa Keyserling, 1892: 110-112, pl. 6, figs 82, 82a-b (three female syntypes from Bogotá, Colombia, BMNH, examined).

Eustala decemtuberculata Caporiacco, 1955: 342-343, figs 28a, b (female holotype from Rancho Grande, Aragua, Venezuela, 13.VIII.1949, Racenis leg., MBUV 697, examined). Syn. nov. Parawixia rimosa, Levi, 1992: 15, figs 6, 32-39.

\section{Kapogea isosceles (Mello-Leitão, 1939), comb. nov.}

Eustala isosceles Mello-Leitão, 1939: 62-63, figs 32-33 (immature holotype from Paraguay, C. Ternetz leg., NHMB, examined); Levi, 2008.

Cyrtophora alayoi Archer, 1958: 9, figs 14-16 (male holotype from Banes, Province of Oriente, Cuba, AMNH, examined). Syn. nov.

Kapogea alayoi, Levi, 1997: 246-249, figs 133-139.

Remarks. Eustala isosceles was described based on an immature specimen, which is currently in poor conditions, almost without coloration and with all the legs lost. However, the remaining coloration and the habitus clearly indicate it is a member of Kapogea alayoi. Additionally, the type locality of E. isosceles is located inside the extensive distribution range of $K$. alayoi.

\section{Micrathena Sundevall, 1833 Micrathena beta di Caporiacco, 1947 Figs 2-4}

Micrathena beta Caporiacco, 1947: 26 (male holotype from Two Mouths, Essequibo River, Guyana, MZUF, examined). Levi, 1985: 446 (transferred to Linyphiidae, incertae sedis); Berdondini \& Whitman, 2003: 126.

Remarks. The holotype was described by CAPORIACCO (1947) in four lines, without any illustration. It has the left palpus missing and the right one partly expanded. The illustrations in Figs 3 and 4 are mirror images of the right palpus. 

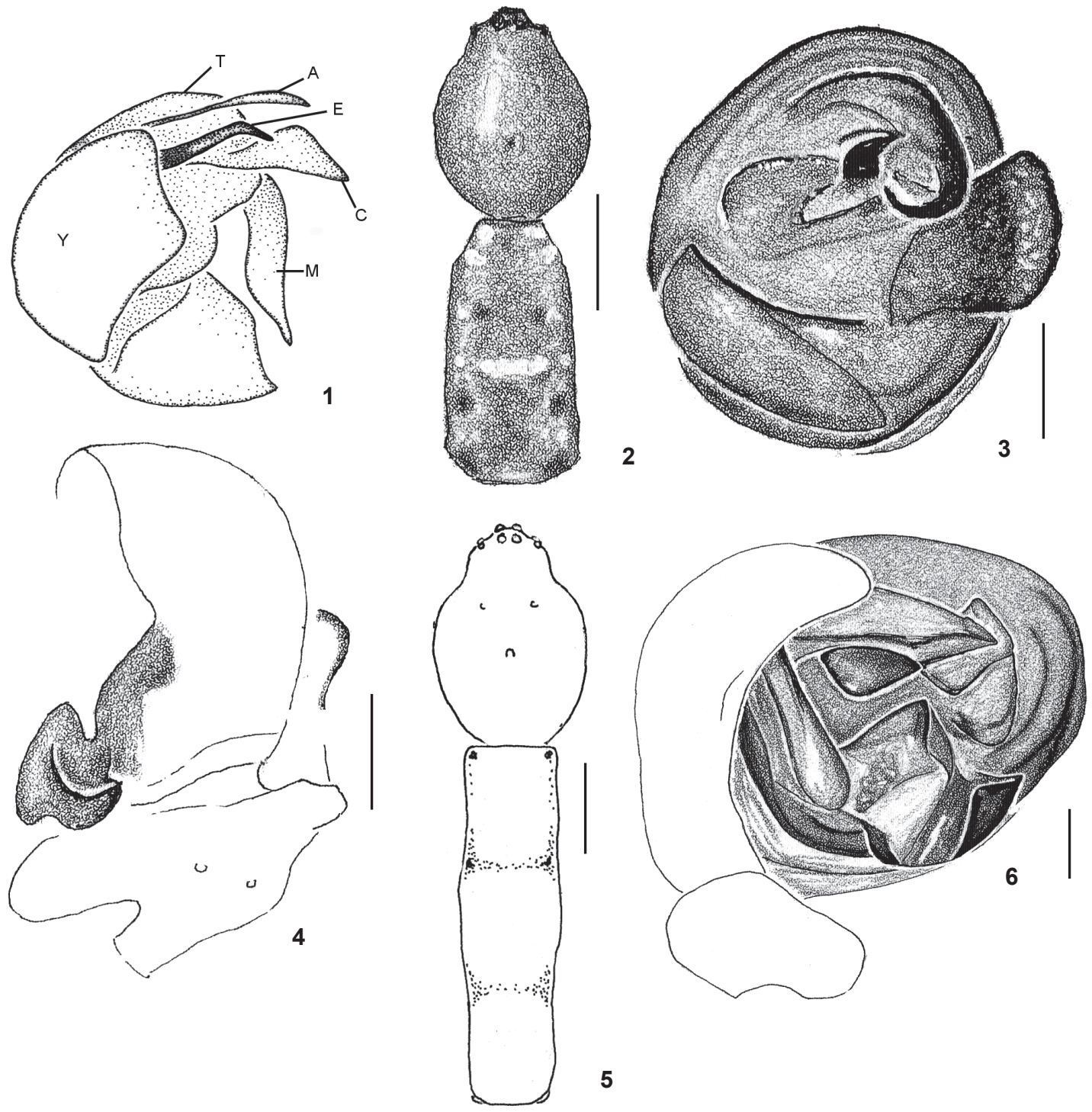

Figure 1-6. Male araneid spiders. (1) Acusilas lepidus, male holotype, left palpus (schematic), ventral view; (2-4) Micrathena beta, male holotype: (2) habitus, dorsal view; (3) mirror image of right palpal bulb, ventral view; (4) mirror image of right cymbium, paracymbium and tibia, ectal view; (5-6) Micrathena lindenbergi, male (holotype of M. parallela): (5) habitus, dorsal view; (6) left palpus, ventral view. (A) Terminal apophysis, (C) conductor, (E) embolus, (M) median apophysis, (T) tegulum, (Y) cymbium. Scale bars: 2, 3, $5=0.1 \mathrm{~mm} ; 4=1.0 \mathrm{~mm}$.

Diagnosis. This is an unusual species of Micrathena, with the palpus having an enlarged and modified paracymbium and a strangely modified tibia (Fig. 4). It closely resembles $M$. lata Chickering, 1960 (Levi 1985: 567, figs 614-615), but differs by having a narrower hook as a conductor (Fig. 3), a more elaborate paracymbium and a slightly differently shaped tibia (Fig. 4).

Description. Male (holotype). Prosoma brown, clypeus and chelicerae lighter brown. Sternum dark brown, coxae lighter, legs not ringed, distal articles lighter brown. Abdomen brown with light and dark patches (Fig. 2), venter brown with a wide gray ring around spinnerets. Posterior median eyes the largest, remaining eyes with about 0.6 times their diameter. Anterior median eyes 1.2 diameters apart, 3.0 from laterals. Posterior median eyes 1.2 diameters apart, 2.5 from laterals. Height of clypeus equals to 0.8 diameter of anterior median eyes. Total length 3.7. Carapace 1.7 long, 1.3 wide. First femur 1.0, patella and tibia 1.3 , metatarsus 0.6 , tarsus 0.4 . Second patella and tibia 1.0 , third 0.8 , fourth 1.2 . 
Micrathena sanctispiritus Brignoli, 1983, sp. reval. Figs 5-6

Micrathena parallela Mello-Leitão, 1940: 200 (male holotype from Colatina, Espírito Santo, Brazil, M. Rosa leg.1936-1937, in MNRJ, examined). Silva Moreira et al., 2010: 19.

Micrathena sanctispiritus Brignoli, 1983: 249. New name for $M$. parallela Mello-Leitão, preoccupied by Micrathena parallela O.P.-Cambridge, 1890. First synonymized with Micrathena lindenbergi Mello-Leitão, 1940 by Levi, 1985: 502.

Micrathena guanabara Levi, 1985: 505, figs 283-289 (female holotype and male paratype from Rio de Janeiro, Rio de Janeiro, Brazil, P. Wygodzinsky leg., 29.I.1945, MCZ, examined). Syn. nov.

Remarks. The male holotype was found shortly after the publication of Levi's (1985) revision of Micrathena. In that study, $M$. sanctispiritus was erroneously synonymized with $M$. lindenbergi because both species were collected at the same locality. For a diagnosis and description see Micrathena guanabara in Levi (1985).

\section{ACKNOWLEDGMENTS}

We are most thankful to Wayne Maddison, to an anonymous reviewer and to Antonio D. Brescovit for critical reading early versions of the manuscript, and the curators of the collections for making the types available for examination. In particular, H.W.L. is grateful to the late Anna Timotheo da Costa for finding the lost type material of M. parallela in the MNRJ collection. A.J. Santos was financially supported by CNPq (procs. 472976/2008-7 and 300498/2009-8), FAPEMIG (PPM-00553-11) and Instituto Nacional de Ciência e Tecnologia dos Hymenoptera Parasitóides da Região Sudeste Brasileira).

\section{LITERATURE CITED}

Alayón, G. 1995. Lista de las arañas (Arachnida: Araneae) de Cuba. Cocuyo 4: 16-26.

ArCHER, A.F. 1958. Studies in the orbweaving spiders (Argiopidae). 4. American Museum Novitates 1922: 1-21.

Berdondini. I. \& S. Whitman. 2003. Cataloghi del Museo di Storia Naturale dell’Università di Firenze - Sezione di Zoologia "La Specola". XVI Arachnida Araneae: Tipi. Atti della Società Toscana di Scienze Naturali, Serie B 108: 119-156.

BRIGNOLI, P. 1983. A catalogue of the Araneae described between 1940 and 1981. Manchester, Manchester University Press, $755 \mathrm{p}$.

Cambridge, F.O.P.-. 1904. Arachnida - Araneida and Opiliones. Biologia Centrali-Americana, Zoology, 2: 465-560.

Caporiacco, L. DI. 1947. Diagnosi Preliminari di Specie Nuove di Aracnidi della Guiana Britannica Raccolte dal Professori Beccari E. Romoti. Monitore Zoologico Italiano 56: 20-34.

CAPORIACCO, L. DI 1955. Estudios sobre los aracnidos de Venezuela. 2a parte: Araneae. Acta Biológica Venezuelica 1: 265-448.
Chamberlin, R.V. 1916. Results of the Yale Peruvian Expedition of 1911. The Arachnida. Bulletin of the Museum of Comparative Zoology, Harvard University 60: 177-299.

Chamberlin, R.V. 1925. Diagnoses of new American Arachnida. Bulletin of the Museum of Comparative Zoology, Harvard University 67: 209-248.

Chickering, A.M. 1955. The genus Eustala (Araneae, Argiopidae) in Central America. Bulletin of the Museum of Comparative Zoology, Harvard University 112: 391-518.

FranganilLo, P. 1931. Excursiones arachnológicas, durante el mes de agosto de 1930. Estudios de "Belen" 29: 44-49.

Franganillo, P. 1936. Los Arácnidos de Cuba hasta 1936. Habana, Cultural, 178p.

KEYSERLING, E. 1864. Beschreibungen neuer und wenig bekannter Arten aus der Familie Orbitelae Latr. oder Epeiridae Sund. Sitzungsberichte der naturwissenschaftlichen Gesellschaft Isis zu Dresden 1863: 119-154.

KeyserLing, E. 1892. Die Spinnen Amerikas. Epeiridae. Nürnberg 4: 1-208.

Levi, H.W. 1977. The American Orb-weaver Genera Cyclosa, Metazygia and Eustala North of Mexico (Araneae: Araneidae). Bulletin of the Museum of Comparative Zoology, Harvard University 148: 61-127.

Levi, H.W. 1978. The American orb-weaver genera Colphepeira, Micrathena and Gasteracantha north of Mexico (Araneae, Araneidae). Bulletin of the Museum of Comparative Zoology, Harvard University 148: 417-442.

Levi, H.W. 1983. The orb-weaver genera Argiope, Gea, and Neogea from the western Pacific region (Araneae: Araneidae, Argiopinae). Bulletin of the Museum of Comparative Zoology, Harvard University 150: 247-338.

Levi, H.W. 1985. The Spiny Orb-Weaver Genera Micrathena and Chaetacis (Araneae: Araneidae). Bulletin of the Museum of Comparative Zoology, Harvard University 150: 429-618.

Levi, H.W. 1991. The Neotropical and Mexican species of the orb-weaver genera Araneus, Dubiepeira, and Aculepeira (Araneae: Araneidae). Bulletin of the Museum of Comparative Zoology, Harvard University 152: 167-315.

LevI, H.W. 1992. Spiders of the orb-weaver genus Parawixia in America (Araneae: Araneidae). Bulletin of the Museum of Comparative Zoology, Harvard University 153: 1-46.

Levi, H.W. 1995. The neotropical orb-weaver genus Metazygia (Araneae: Araneidae). Bulletin of the Museum of Comparative Zoology, Harvard University 154: 63-151.

Levi, H.W. 1997. The American orb-weavers of the genera Mecynogea, Manogea, Kapogea and Cyrtophora (Araneae: Araneidae). Bulletin of the Museum of Comparative Zoology, Harvard University 155: 215-255.

LEVI, H.W. 2002. Keys to the genera of araneid orbweavers (Araneae, Araneidae) of the Americas. Journal of Arachnology 30: 527562.

Levi, H.W. 2004. Comments and new records for the American genera Gea and Argiope with the description of a new species 
(Araneae: Araneidae). Bulletin of the Museum of Comparative Zoology, Harvard University 158: 47-65.

Levi, H.W. 2007. The orb weaver genus Mangora in South America (Araneae, Araneidae). Bulletin of the Museum of Comparative Zoology, Harvard University 159: 1-144.

Levi, H.W. 2008. Unpublished drawings of araneid and tetragnathid species by Herbert Levi. Available online at: http://www.oeb.harvard.edu/faculty/levi [Accessed: 31/I/2013].

Levi, H.W.; A.J. Santos \& A.D. Brescovit. 2010. Orb-weaving spider species illustrated by H.W. Levi. Available online at: http://www.butantan.gov.br/typesoflevi/araneidae.htm [Accessed: 31/I/2013].

Magalhães I.L.F. \& A.J. Santos. 2011. Two new species and taxonomic notes on the Neotropical spiny orb-weaving spiders Micrathena and Chaetacis (Araneae: Araneidae), with remarks on the development of Micrathena excavata. Zootaxa 2983: 39-56.

Magalhães I.L.F. \& A.J. Santos. 2012. Phylogenetic analysis of Micrathena and Chaetacis spiders (Araneae: Araneidae) reveals multiple origins of extreme sexual size dimorphism and long abdominal spines. Zoological Journal of the Linnean Society 166: 14-53.

Mello-LeitÃo, C.F. 1939. Some new Argiopid Spiders of British Guiana taken by Mr C. W. Richards from the Nests of solitary Wasps. Annaes da Academia Brasileira de Sciencias 11: 105112.

Mello-Leitão, C.F. 1939. Araignées américaines du Musee d'histoire naturelle de Bâle. Revue Suisse de Zoologie 46: 43-93.

Submitted: 04.VIII.2012; Accepted: 18.II.2013.

Editorial responsibility: Antonio D. Brescovit
Mello-Leitão, C.F. 1940. Aranhas do Espírito Santo coligidas per M. Rosa, em 1936 e 1937. Archivos de Zoologia do Estado de São Paulo 2: 199-214.

Mello-Leitão, C.F. 1948. Contribuição ao conhecimento da fauna araneológica das Guianas. Anais da Academia Brasileira de Ciencias 20: 151-196.

Platnick, N. I. 2013. The world spider catalog, version 13.5. American Museum of Natural History, online at: http:// research.amnh.org/iz/spiders/catalog, doi: 10.5531/ db.iz.0001 [Accessed: 31/I/2013].

Poeta, M.R.M.; M.A.L. Marques \& E.H. Buckup. 2010. Sobre algumas espécies do gênero Eustala (Araneae, Araneidae) do Brasil. Iheringia, Série Zoologia, 100: 267-274.

Santos, A.J.; A.D. Brescovit \& H.W. Levi. 2005. Melychiopharis: an atypical orb-weaving spider from South America (Araneae: Araneidae). Zootaxa 1016: 57-64.

Scharf, N. \& J.A. Coddington. 1997. A phylogenetic analysis of the orb-weaving spider family Araneidae (Arachnida, Araneae). Zoological Journal of the Linnean Society 120: 355-434.

Schmidt, J. B. \& N. ScharfF. 2008. A taxonomic revision of the orb-weaving spider genus Acusilas Simon, 1895 (Araneae, Araneidae). Insect Systematics and Evolution 39: 1-38.

Silva Moreira, T.; R.L.C. Baptista; A.B. Kury; A.P.L. Giupponi; E.H. Buckup \& A.D. Brescovit. 2010. Annotated check list of Arachnida type specimens deposited in the Museu Nacional, Rio de Janeiro. II - Araneae. Zootaxa 2588: 1-91.

Taczanowski, L. 1873. Les Aranéides de la Guyane Française. Horae Societatis entomologicae Rossicae 9: 113-150. 